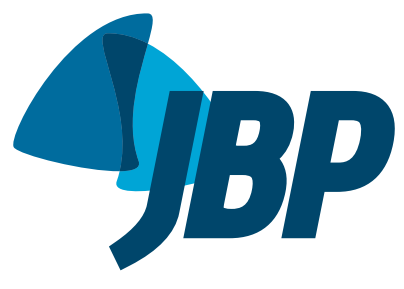

\title{
False-negative newborn screening result for immunoreactive trypsinogen: a major problem in children with chronic lung disease
}

\author{
Magali Santos Lumertzi,a, Thaiane Rispoli2,b Katiana Murieli da Rosa ${ }^{3, c}$, \\ Leonardo Araújo Pinto ${ }^{3,4, d}$
}

\section{TO THE EDITOR:}

For patients with cystic fibrosis (CF), specialized multidisciplinary care is important, as is early diagnosis to prevent or delay CF-related complications. Therefore, the CF newborn screening test for immunoreactive trypsinogen (IRT) is essential. ${ }^{(1)}$ Because many patients are asymptomatic when the test is performed, prophylactic and therapeutic interventions can be implemented in a timely manner, and this increases their efficacy. ${ }^{(2,3)}$ However, false-positive and false-negative results can occur, the latter being less common than the former. Both are undesirable for screening and ideally should not occur. Factors associated with false-positive results are more commonly reported in the literature than are those associated with false-negative results; in addition, an increased number of follow-up studies have examined the potential psychosocial impact of false-positive results on children and their families, showing no persistent psychosocial harm despite immediate distress following notification of the positive result. ${ }^{(4)}$ False-negative results can occur in newborns with meconium ileus (MI), which is strongly associated with $\mathrm{CF}$, as well as in those in whom a high cut-off point is used and in those in whom there is a delay between the date of birth and the date of dried blood spot (DBS) sample collection; in addition, false-negative results can be attributed to laboratory errors, including inefficient elution of DBS samples on filter paper. ${ }^{(5,6)}$

At our multidisciplinary tertiary care center for CF we identified four patients whose IRT test results were interpreted as false negative because they were below the cut-off point used in the laboratory in which the tests were performed. The characteristics of the patients are summarized in Table 1. All four were male and White. Two had had MI at birth and therefore required a temporary ileostomy. Their IRT levels were $98.7 \mathrm{ng} / \mathrm{mL}$ (DBS samples having been collected in the first week of life) and 88.5 $\mathrm{ng} / \mathrm{mL}$ (IRT testing having been performed at around the age of one month), the laboratory reference value being $110 \mathrm{ng} / \mathrm{mL}$. The two patients underwent sweat testing and genotyping, a diagnosis of CF being established before neonatal discharge. A third patient underwent newborn screening at the age of 14 days. However, the IRT test for CF was not performed because it was not part of the routine newborn screening panel performed in the state public health system at the time. Because of recurrent respiratory infections requiring hospitalization in the first year of life and because of subnormal weight and height at around the age of six months, the attending physician requested an expanded newborn screening panel including IRT testing, the results of which were reported as normal. Intestinal obstruction requiring laparotomy, together with the aforementioned clinical changes, again raised the suspicion of CF. The patient underwent sweat testing, which confirmed the diagnosis of $\mathrm{CF}$, specialized outpatient treatment being initiated. In addition to having been colonized with Staphylococcus aureus, the patient had positive cultures for Pseudomonas aeruginosa, which became negative after $P$. aeruginosa eradication therapy. A fourth patient underwent newborn screening at the age of six days, his IRT level being $39.4 \mathrm{ng} / \mathrm{mL}$ (laboratory reference value, $110 \mathrm{ng} / \mathrm{mL}$ ). Because of growth deficit, as well as recurrent steatorrhea, cough, and wheezing, the patient underwent sweat testing (at the age of three years), his sweat chloride level being $118 \mathrm{mmol} / \mathrm{L}$ in a 231-g sample.

In countries where CF newborn screening is performed, ${ }^{(7)}$ different protocols are used, all of which have advantages and disadvantages. In Brazil, in the states in which CF newborn screening is routinely performed, a diagnostic test (usually a sweat test) is performed in patients whose IRT levels are measured twice and found to be elevated on both measurements (the IRT/IRT protocol). In the state of Rio Grande do Sul, IRT measurement was officially added to the routine newborn screening panel in June of 2012. In developed countries, CF newborn screening protocols include genetic testing for common mutations in the CFTR gene, which encodes the cystic fibrosis transmembrane conductance regulator protein, and CFTR gene sequencing (the IRT/DNA protocol). ${ }^{(8)}$ In a study conducted in France, the IRT/DNA protocol and the IRT/pancreatitis-associated protein protocol were compared in terms of their performance in CF newborn screening, the latter being found to be not inferior to the former in screening for CF. ${ }^{(9)}$

Although the CF newborn screening test for IRT identifies $95-99 \%$ of newborns with CF (depending on the screening protocol used), false-negative results can 
Table 1. Patient characteristics.

\begin{tabular}{|c|c|c|c|c|c|c|c|c|}
\hline Case & $\begin{array}{c}\text { IRT } \\
\text { level/ } \\
\text { RV (ng/ } \\
\text { mL)* }\end{array}$ & $\begin{array}{c}\text { Sweat } \\
\text { chloride } \\
\text { concentration } \\
\text { (mmol/L) }\end{array}$ & Genotype & $\begin{array}{l}\text { Meconium } \\
\text { ileus }\end{array}$ & $\begin{array}{l}\text { Low } \\
\text { weight } \\
\text { gain } \\
\text { prior to } \\
\text { diagnosis }\end{array}$ & $\begin{array}{c}\text { Recurrent } \\
\text { respiratory } \\
\text { infections }\end{array}$ & $\begin{array}{c}\text { Use of } \\
\text { pancreatic } \\
\text { enzymes }\end{array}$ & $\begin{array}{c}\text { Airway } \\
\text { bacterial } \\
\text { colonization }\end{array}$ \\
\hline 1 & $98.7 / 110$ & 85 & $\begin{array}{l}\text { F508del/ } \\
\text { R1162X }\end{array}$ & $x$ & & & $x$ & MRSA \\
\hline 2 & $88.5 / 110$ & 54 & $\begin{array}{c}\text { F508del/ } \\
\text { F508del }\end{array}$ & $x$ & & & $x$ & SA \\
\hline 3 & a & 111 & $\begin{array}{l}\text { F508del/ } \\
\text { R1162X }\end{array}$ & & $x$ & $x$ & $x$ & SA \\
\hline 4 & $39.4 / 110$ & 118 & $\begin{array}{c}\text { F508del/ } \\
\text { F508del }\end{array}$ & & $x$ & $x$ & $x$ & SA \\
\hline
\end{tabular}

IRT: immunoreactive trypsinogen; RV: reference value; MRSA: methicillin-resistant Staphylococcus aureus; and

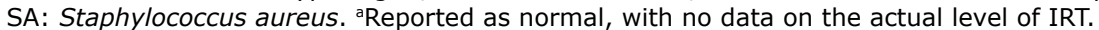

delay diagnosis, particularly when IRT levels are within the normal range and the clinical signs of the disease are overlooked. ${ }^{(10)}$ It should be borne in mind that IRT measurement is not a diagnostic test. ${ }^{(5)}$ Therefore, regardless of serum IRT levels, sweat testing should be performed in all patients clinically suspected of having $\mathrm{CF}$, including those with a negative IRT level and MI, as well as those whose parents have CF-associated mutations. ${ }^{(10)}$ Factors associated with false-negative results were identified in three of the four patients in the present study: two had had MI at birth, which raised the suspicion of $\mathrm{CF}$ and led to further diagnostic testing; and one underwent IRT testing at around the age of six months, by which time clinical symptoms had appeared, leading to misinterpretation of the results and delayed diagnosis. In the remaining patient (whose IRT level was $39.4 \mathrm{ng} / \mathrm{mL}$ ), no false-negative-associated factors were identified.
One group of authors described cases of false-negative newborn screening results despite the use of CFTR gene analysis as a screening strategy. ${ }^{(5)}$ In a study evaluating the newborn screening program in the state of Paraná, Brazil, 30 months after its implementation, (11) only one case of a false-negative newborn screening result was found. In a study involving two centers for CF newborn screening in the state of São Paulo, Brazil, no false-negative results were found over a period of nearly two years. ${ }^{(12)}$

Because CF newborn screening allows timely implementation of therapeutic interventions, a diagnosis of CF should not be based on serum IRT levels alone. Regardless of their serum IRT levels, patients presenting with clinical signs and symptoms suggestive of $\mathrm{CF}$, as well as those with $\mathrm{MI}$ at birth and those with CF siblings, should undergo sweat testing, CFTR gene sequencing, or both.

\section{REFERENCES}

1. Crossley JR, Elliott RB, Smith PA. Dried-blood spot screening for cystic fibrosis in the newborn. Lancet. 1979;1(8114):472-4. https:// doi.org/10.1016/S0140-6736(79)90825-0

2. Stocks J, Thia LP, Sonnappa S. Evaluation and use of childhood lung function tests in cystic fibrosis. Curr Opin Pulm Med. 2012;18(6):602 8. https://doi.org/10.1097/MCP.0b013e328358dfbe

3. Farrell PM, Kosorok MR, Rock MJ, Laxova A, Zeng L, Lai HC, et al. Early diagnosis of cystic fibrosis through neonatal screening prevents severe malnutrition and improves long-term growth. Wisconsin Cystic Fibrosis Neonatal Screening Study Group. Pediatrics. 2001;107(1):1-13. https://doi.org/10.1542/peds.107.1.1

4. Hayeems RZ, Miller FA, Barg CJ, Bombard Y, Kerr E, Tam K, et al. Parent Experience With False-Positive Newborn Screening Results for Cystic Fibrosis. Pediatrics. 2016;138(3): pii: e20161052. https:// doi.org/10.1542/peds.2016-1052

5. Dunn CT, Skrypek MM, Powers AL, Laguna TA. The need for vigilance: the case of a false-negative newborn screen for cystic fibrosis. Pediatrics. 2011;128(2):e446-9. https://doi.org/10.1542/ peds.2010-0286

6. Kloosterboer M, Hoffman G, Rock M, Gershan W, Laxova A, Li Z, et al. Clarification of laboratory and clinical variables that influence cystic fibrosis newborn screening with initial analysis of immunoreactive trypsinogen. Pediatrics. 2009:123(2):e338-46. https://doi. org/10.1542/peds.2008-1681
7. Southern KW. Determining the optimal newborn screening protoco for cystic fibrosis. Thorax. 2012;67(4):281-2. https://doi.org/10.1136/ thoraxjnl-2012-201589

8. Southern KW, Munck A, Pollitt R, Travert G, Zanolla L, DankertRoelse J, et al. A survey of newborn screening for cystic fibrosis in Europe. J Cyst Fibros. 2007;6(1):57-65. https://doi.org/10.1016/]. jcf.2006.05.008

9. Sarles J, Giorgi R, Berthézène P, Munck A, Cheillan D, Dagorn JC, et al. Neonatal screening for cystic fibrosis: comparing the performances of IRT/DNA and IRT/PAP. J Cyst Fibros. 2014;13(4):384-90. https:// doi.org/10.1016/j.jcf.2014.01.004

10. Comeau AM, Accurso FJ, White TB, Campbell PW 3rd, Hoffman G. Parad RB, et al. Guidelines for implementation of cystic fibrosis newborn screening programs: Cystic Fibrosis Foundation workshop report. Pediatrics. 2007;119(2):e495-518. https://doi.org/10.1542/ peds.2006-1993

11. Santos GP, Domingos MT, Wittig EO, Riedi CA, Rosário NA. Neonata cystic fibrosis screening program in the state of Paraná: evaluation 30 months after implementation [Article in Portuguese]. J Pediatr (Rio J). 2005;81(3):240-4. https://doi.org/10.2223/JPED.1345

12. Rodrigues R, Magalhaes PK, Fernandes MI, Gabetta CS, Ribeiro AF Pedro KP, et al. Neonatal screening for cystic fibrosis in São Paulo State, Brazil: a pilot study. Braz J Med Biol Res. 2009;42(10):973-8. https://doi.org/10.1590/S0100-879X2009005000017 